\title{
Development of an assessment methodology for innovation activity of construction enterprises
}

\author{
Natalia Shovunova ${ }^{1, *}$, Dmitry Vorobyev ${ }^{1}$, Varvara Dikareva ${ }^{2}$, Svetlana Archakova $^{3}$ and \\ Yelena Serebryakova ${ }^{3}$ \\ ${ }^{1}$ Moscow state University of technology and management. K.G. Razumovsky, Zemlyanoy Val street, \\ 73, Moscow, 109004, Russia \\ ${ }^{2}$ Moscow State University of Civil Engineering, Yaroslavskoye shosse, 26, Moscow, 129337, Russia \\ ${ }^{3}$ Voronezh State Technical University, Moscow Avenue, 14, Voronezh, 394026, Russia
}

\begin{abstract}
The purpose of this paper is to develop an assessment methodology for innovation activity of construction enterprises. The ability of the enterprise to react clearly and appropriately to the changes in the market through the release of new products or improvement of existing products, the introduction of new production and marketing technologies, the improvement of a system of internal company management, and the use of the latest marketing strategies are the key components. As a result of this study, the indicators of conditions and results of innovation activity were analyzed, an algorithm for the methodic of a comprehensive assessment of the efficiency of innovation activity was developed, and a typology of construction enterprises was structured according to the level of development of innovation activity. Innovative development, competitiveness and sustainable development of enterprises are achieved through the systematic introduction of innovations.
\end{abstract}

\section{Introduction}

The main condition for the productivity of construction enterprises is the identification of an economic indicator or a group of indicators. It is also the final element of the efficiency development of innovation activity in order to increase the competitiveness and efficiency of the enterprise. These indicators will provide an opportunity to make the correct conclusion about the feasibility of implementation of the innovative project.

Therefore, the methods, indicators and specifics of the assessment of innovation activity described in the study should be included in the unified system for assessing the efficiency of an innovative project in the construction industry [1].

In our point of view, the system of comprehensive analysis of innovations should analyze all parts and stages of innovation activity, characterize the unity of quantitative and qualitative methods of analysis, and should be aimed at finding the result in implementation

\footnotetext{
${ }^{*}$ Corresponding author: 1304847@list.ru
} 
of the main objectives of the activity of construction enterprises. In order to assess the efficiency of the innovation activity of the enterprise, it is necessary not only to correctly choose and determine the values of the system of economic indicators, but also to show the feasibility of using them in the reality [2]. That is why this system should give an unbiased assessment of the actual state of innovation activity of the studied construction enterprises.

\section{Materials and methods}

In order to assess the efficiency of the innovation activity of the enterprise, it is necessary not only to correctly choose and determine the values of the economic indicator system, but also to show the feasibility of using them in the reality. That is why this system should give an unbiased assessment of the actual state of innovation activity of the studied construction enterprises. It should also take into account the distinctive features of the production system, the specifics of innovative processes in the construction industry, and the category of production. Accordingly to the results of determination of the relationship between innovation analysis and comprehensive economic analysis of enterprises, we selected and grouped the following blocks of performance indicators (Table 1).

Table 1. The indicators of conditions and results of innovation activity of the construction enterprises.

\begin{tabular}{|c|c|c|c|c|}
\hline $\begin{array}{l}\text { Group of } \\
\text { specifics }\end{array}$ & $\begin{array}{l}\text { Specific of } \\
\text { enterprise }\end{array}$ & $\begin{array}{l}\text { Specific of } \\
\text { innovation } \\
\text { activity }\end{array}$ & $\begin{array}{l}\text { Block of } \\
\text { indicators }\end{array}$ & Objectives of assessment \\
\hline Economic & $\begin{array}{l}\text { Limited resource } \\
\text { potential and } \\
\text { dependence on } \\
\text { domestic funding } \\
\text { sources }\end{array}$ & \begin{tabular}{c|} 
The \\
predominance of \\
economizing or \\
effect-adding \\
adopted \\
production \\
innovations \\
\end{tabular} & $\begin{array}{l}\text { Economic } \\
\text { (financial) } \\
\text { indicators }\end{array}$ & $\begin{array}{l}\text { Assessment of the possibilities } \\
\text { for self-financing of } \\
\text { independent entrepreneurs, } \\
\text { assessment of the possibility of } \\
\text { taking a credit, assessment of } \\
\text { financial feasibility and } \\
\text { innovation activity } \\
\end{array}$ \\
\hline Organizational & $\begin{array}{l}\text { Simplified } \\
\text { organizational } \\
\text { structure }\end{array}$ & $\begin{array}{c}\text { Absence of high- } \\
\text { cost innovation }\end{array}$ & \begin{tabular}{|c|} 
Indicators of the \\
level of \\
production and \\
management \\
organization
\end{tabular} & $\begin{array}{l}\text { Assessment of the existing level } \\
\text { of production and management } \\
\text { organization, the search for } \\
\text { reserves for innovations }\end{array}$ \\
\hline Produ & $\begin{array}{l}\text { Flexibility and } \\
\text { operational } \\
\text { efficiency of the } \\
\text { formation of the } \\
\text { project portfolio }\end{array}$ & $\begin{array}{c}\text { The } \\
\text { predominance of } \\
\text { product } \\
\text { innovations }\end{array}$ & $\begin{array}{l}\text { Indicators of } \\
\text { production } \\
\text { activity of the } \\
\text { enterprise }\end{array}$ & $\begin{array}{c}\text { Assessment of production } \\
\text { capacity, determination of } \\
\text { necessity for updating the fixed } \\
\text { funds, assessment of resource } \\
\text { efficiency, assessment of the } \\
\text { necessity to replace resources } \\
\text { with the new ones } \\
\end{array}$ \\
\hline Reg & \begin{tabular}{|c|} 
Legal flexibility \\
along with the low \\
political potential
\end{tabular} & $\begin{array}{l}\text { Application of } \\
\text { innovations } \\
\text { primarily to non-1 } \\
\text { state orders }\end{array}$ & \begin{tabular}{|c|} 
Accounting \\
when choosing \\
he innovation by \\
methods of the \\
theory of matrix \\
games
\end{tabular} & $\begin{array}{l}\text { Assessment of transaction } \\
\text { expenses }\end{array}$ \\
\hline $\begin{array}{l}\text { External } \\
\text { (market) }\end{array}$ & $\begin{array}{c}\text { Unstable, } \\
\text { gggressive nature of } \\
\text { the environment }\end{array}$ & $\begin{array}{c}\text { The } \\
\text { predominance of } \\
\text { economizing } \\
\text { innovations }\end{array}$ & $\begin{array}{l}\text { Indicators of } \\
\text { resistance to } \\
\text { external factors }\end{array}$ & $\begin{array}{c}\text { Assessment of the market } \\
\text { situation and prospects due to } \\
\text { he growth of innovative activity } \\
\text { of competitors, stability } \\
\text { assessment }\end{array}$ \\
\hline
\end{tabular}


Based on the above, it is possible to consider the algorithm for a comprehensive assessment of the efficiency of innovation for small and medium-sized businesses in the construction sector (a flowchart is presented in Figure 1.). This algorithm characterizes the assumptions and results of innovation activity, integrates the calculation and expert methods of assessment, projects the impact of the innovation introduction results on the objective orientation of the enterprise and its production activities, and also implements the functions of analysis and control when making management decisions.

The proposed algorithm of the methodic of a comprehensive assessment of the efficiency of innovation uses economic indicators determined by the reporting of enterprises, and allows not only to assess the dynamics, but also to conduct a factor analysis of the results of innovation activities of enterprises [3].

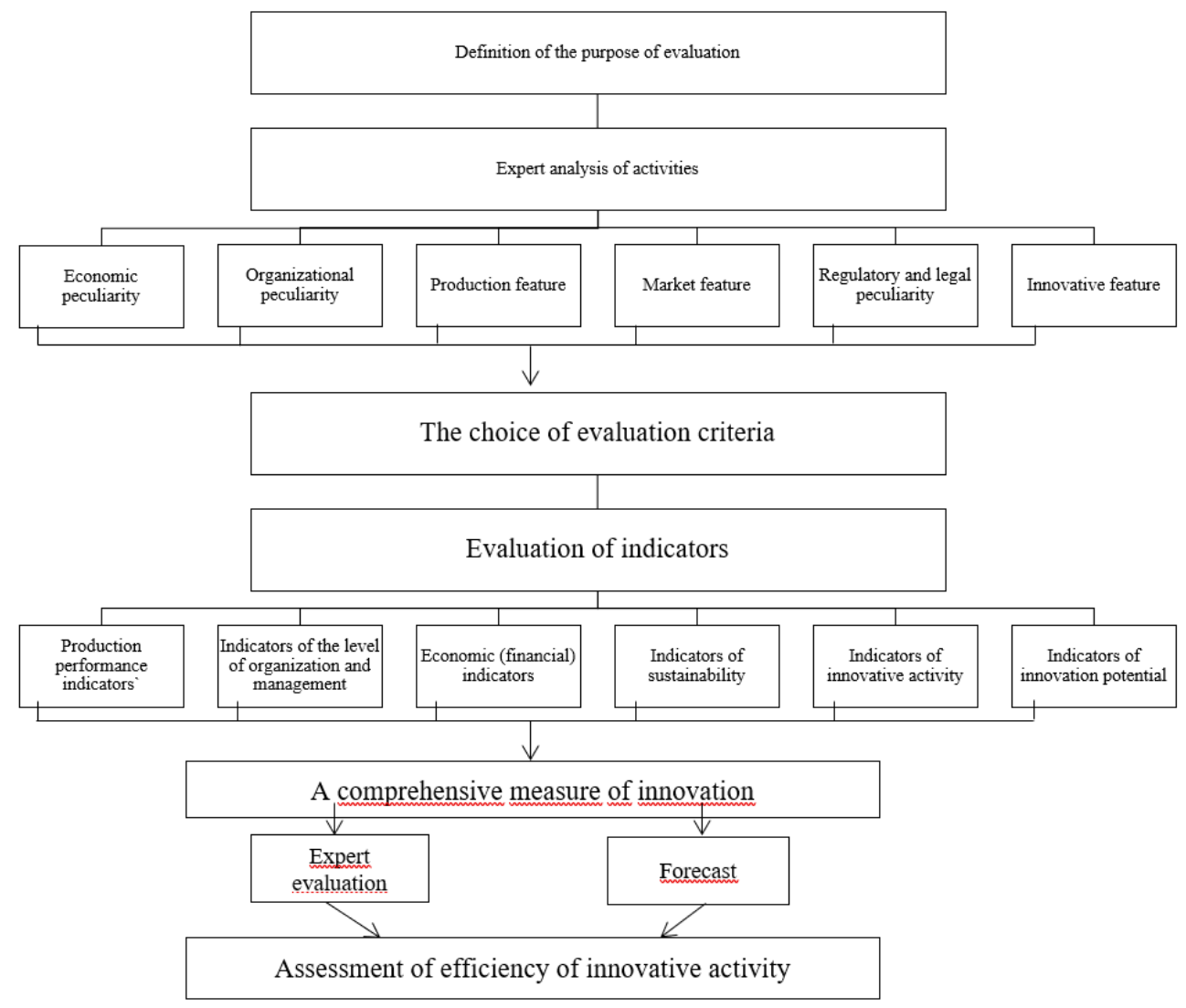

Fig. 1. An algorithm of the methodic of a comprehensive assessment of the efficiency of innovation activity of construction enterprises.

Forming a system of indicators revealing the innovative activity of construction enterprises, we were guided by the following points: indicators should express the essence of innovative activity of enterprises and give it an accurate quantitative and qualitative assessment; they should be comprehensive and multifaceted, allowing to obtain the broad and diversified characteristics of the state of innovative activity of enterprises; indicators should ensure the reliability, completeness and timeliness of obtaining the initial information for their calculation; indicators should take into account possible changes in the conditions and objectives of innovation activity of enterprises; indicators should be 
connected to the current statistical reporting system [4]. The list of main indicators is presented in Table. 2 .

\section{Results}

Since the definition of the state of innovation activity can't be fully mathematically formalized, the most acceptable method, in our opinion, is the method of expert assessment (Delphi method). This approach was chosen due to the fact that the average value is a summing up indicator, an expression of the essence of a number of parameters in one number.

Let's consider the stagewise expert assessment (Table 2). Firstly, the expert group selects and qualitatively analyzes the indicators that have the greatest impact on the innovation activity of the enterprises being assessed. The list of key indicators of innovation activity of enterprises is unique for all of them and is widely represented in the scientific literature $[5,6]$.

The structure of the group can include both employees of these construction enterprises, and external experts who specialize in the area of innovation, the development of innovative projects, and financing of innovation activity. The level of competence of experts should be taken into account at the stage of group formation, and all experts should be considered equally competent.

Table 2. An algorithm of stagewise expert assessment.

\begin{tabular}{|c|c|c|c|}
\hline № & Stage description & $\begin{array}{c}\text { Formula for } \\
\text { calculation }\end{array}$ & Conventional signs \\
\hline 1 & $\begin{array}{l}\text { The expert group determines the } \\
\text { weight coefficient for each } \\
\text { indicator, i.e. the significance of } \\
\text { the indicator, taking into account } \\
\text { that the total weight of the } \\
\text { indicators is equal to one }\end{array}$ & $\bar{A}_{i}=\sum_{i=1}^{m} A_{i j} / n$ & $\begin{array}{l}\bar{A}_{i} \text { - average weights (average } \\
\text { significance) of i-th indicator; } \\
A_{i j} \text { - significance of indicator, } \\
\text { given to i-th indicator by j-th } \\
\text { expert; } \\
\text { n- number of experts }\end{array}$ \\
\hline 2 & $\begin{array}{l}\text { Experts carry out an independent } \\
\text { assessment of the impact of } \\
\text { changing indicators on the course } \\
\text { of innovation activity in } \\
\text { accordance with the chosen scale, } \\
\text { then obtained individual } \\
\text { evaluations are being averaged, } \\
\text { and thereby ensuring the } \\
\text { objectivity. }\end{array}$ & $\overline{B_{i}}=\sum_{i=1}^{m}$ & $\begin{array}{l}\overline{B_{i}} \text { - average point of i-th } \\
\text { indicator; } \\
B_{i j} \text { - point, given to i-th } \\
\text { indicator by j-th expert; } \\
\text { n- number of experts }\end{array}$ \\
\hline 3 & $\begin{array}{l}\text { The impact force of a change in an } \\
\text { indicator on the changing of } \\
\text { innovation activity is determined }\end{array}$ & $C_{i}=\bar{A}_{i} \mathrm{~g} \bar{B}_{i}$ & $\begin{array}{l}C_{i} \text { - impact force of the } \\
\text { change of i-th indicator on the } \\
\text { course of innovation activity }\end{array}$ \\
\hline 4 & $\begin{array}{l}\text { Experts determine the average } \\
\text { impact force of the indicators of } \\
\text { each group and select the } \\
\text { indicators whose force of impact } \\
\text { exceeds the average value }\end{array}$ & $\begin{array}{c}\overline{C_{k}}=\sum_{i=1}^{m} C_{i k} / \mathrm{m} \\
\text { verification of } \\
\text { meeting the } \\
\text { condition }\end{array}$ & $\begin{array}{l}\mathrm{k} \text { - factor group (financial } \\
\text { component, personnel, etc.); } \\
\mathrm{m} \text { - number of factors in k-th } \\
\text { group; } \\
C_{i k} \text { - force of impact of } \mathrm{i}-\mathrm{th} \\
\text { indicator of k-th group on } \\
\text { innovative activity }\end{array}$ \\
\hline
\end{tabular}




\begin{tabular}{|c|c|c|c|}
\hline & & $\overline{C_{i k}} \mathrm{f} \overline{C_{k}}$ & \\
\hline 5 & $\begin{array}{l}\text { Definition of individual indices for } \\
\text { each selected indicator, calculated } \\
\text { as the ratio of the value of this } \\
\text { indicator in the considered and } \\
\text { base periods }\end{array}$ & $Y_{\text {ind }}=\frac{I_{1}}{I_{0}}$ & $\begin{array}{l}I_{1} / I_{0}-\text { value of the indicator } \\
\text { in the considered and base } \\
\text { periods }\end{array}$ \\
\hline 6 & $\begin{array}{l}\text { The average index for each group } \\
\text { is calculated as the arithmetic } \\
\text { mean of the individual indices }\end{array}$ & $Y_{k}=\sum_{i=1}^{f_{1}} Y_{i n d} / f_{1}$ & $\begin{array}{l}f_{1} \text { - number of selected } \\
\text { indicators in } \mathrm{k} \text {-th group }\end{array}$ \\
\hline 7 & $\begin{array}{l}\text { Calculation of the level of } \\
\text { innovation which is defined as the } \\
\text { average value of the average } \\
\text { indices of each group }\end{array}$ & $Y_{I D}=\sum_{i=1}^{k} Y_{k} / k_{1}$ & k- number of groups \\
\hline
\end{tabular}

Assessment of the state of innovation activity is the basis for the development of innovation strategy by construction enterprises with the aim of achieving competitive advantages $[7,8]$.

In our opinion, there are three most important main areas in the innovative activity of construction enterprises:

- introduction of resource-saving technologies (process-innovation);

- product differentiation based on the offer of new products;

- creation of new markets based on the offer of radically high quality products.

In accordance with the proposed methodology for assessing the state of innovation activity, various ways of improvement are possible, depending on the characteristics of the components of innovation activity. The possible states of results of the analysis and the most appropriate solutions are presented in Table 3.

The advantages of this methodology are the objectivity caused by the selection of indicators and determination of the level of their impact on innovation activity, as well as the possibility of a unified assessment of heterogeneous indicators that vary in different directions and with different intensity, and the relative simplicity of calculations and clearness of their presentation [9].

That is why the proposed approach makes it possible to identify the state of innovation activity. And depending on the results of the expert assessment, certain recommendations can be proposed to maintain the existing level or to eliminate the weaknesses.

Table 3. Typology of construction enterprises by the level of innovation development.

\begin{tabular}{|l|l|l|}
\hline $\begin{array}{c}\text { State of innovation activity } \\
\text { indicators }\end{array}$ & \multicolumn{1}{|c|}{$\begin{array}{c}\text { Tactical decisions and } \\
\text { recommendations }\end{array}$} & \multicolumn{1}{|c|}{ Type of enterprise } \\
\hline $\begin{array}{l}\text { Normal level } \\
\text { high level of indicators); } \\
\text { high innovation } \\
\text { possibilities }\end{array}$ & $\begin{array}{l}\text { Maintaining the existing level of } \\
\text { indicators }\end{array}$ & $\begin{array}{l}\text { Leader in mastering of } \\
\text { new technologies }\end{array}$ \\
\hline $\begin{array}{l}\text { Acceptable level } \\
\text { (insufficiently high level } \\
\text { of indicators); } \\
\text { average innovative } \\
\text { possibilities }\end{array}$ & $\begin{array}{l}\text { 1.Temporary involvement of third-party } \\
\text { highly qualified specialists } \\
\text { 2. Purchase of scientific and technical } \\
\text { developments } \\
\text { 3. Participation in joint innovation } \\
\text { projects } \\
\text { 4. Modernization and improvement of } \\
\text { the production base }\end{array}$ & $\begin{array}{l}\text { Consistency } \\
\text { mastering of new } \\
\text { technologies } \\
\text { Leader in mastering of } \\
\text { improved technologies }\end{array}$ \\
\hline
\end{tabular}




\begin{tabular}{|l|l|l|}
\hline $\begin{array}{l}\text { Pre-crisis level } \\
\text { (low level of indicators); } \\
\text { low innovative } \\
\text { possibilities }\end{array}$ & $\begin{array}{l}\text { 1. Improvement of the organization of } \\
\text { innovative activity } \\
\text { 2. Upgrade of the production base } \\
\text { 3. Involvement of third-party highly } \\
\text { qualified specialists }\end{array}$ & $\begin{array}{l}\text { Consistency in } \\
\text { mastering of improving } \\
\text { technologies }\end{array}$ \\
\hline $\begin{array}{l}\text { Crisis level } \\
\text { (very low level of } \\
\text { indicators); } \\
\text { low innovative } \\
\text { possibilities }\end{array}$ & Restructuring of the enterprise & $\begin{array}{l}\text { Consistency in } \\
\text { mastering of improving } \\
\text { technologies }\end{array}$ \\
\hline $\begin{array}{l}\text { Critical level } \\
\text { (critical level of } \\
\text { indicators); } \\
\text { zero innovative } \\
\text { possibilities }\end{array}$ & $\begin{array}{l}\text { Measures for financial recovery of the } \\
\text { enterprise }\end{array}$ & Undeveloped enterprise \\
\hline
\end{tabular}

\section{Conclusions}

Innovative development implies the development and implementation of a significant number of innovations (from product to social), the targeted search, the development and implementation of the potential of specific technological, personnel, market and other competencies of enterprises, paying special attention to disclosing the creative potential of employees and the formation of a special innovative culture and receptivity. It is also characterized by a higher level of impact on all areas of activity of construction enterprises. The results of innovative activities at enterprises are the mastering of the production of a new (modernized) product, the introduction of new technology, methods of management organizing, sales of products, the development and implementation of an innovative project.

\section{References}

1. C.J. Adcock, N. Meade, European Journal of Operational Research 259(2), 746-765 (2017)

2. C. Furlong, S. De Silva, K. Gan, L. Guthrie, R. Considine, Journal of Environmental Management 191, 83-95 (2017)

3. K. Anagnostis, K. Alexios, Procedia Economics and Finance 9, 120-132 (2014)

4. L. Shan, A. Yu, Y.Wu, Habitat International 59, 90-100 (2017)

5. E.M. Kiseleva, M.L. Nekrasova, M.A. Mayorova, M.N. Rudenko, V.S Kankhva, International Review of Management and Marketing 6, 95 (2016)

6. S. Wang, European Journal of Operational Research 169, 329-331 (2006)

7. S. Gupta, N. K. Malhotra, Journal of Business Research 69, 5671-5681 (2016)

8. T.W. Chung, The Asian Journal of Shipping and Logistics 32, 257-264 (2016)

9. N.G. Bagautdinova, A.V. Sarkind, I.R. Gafurovc, Procedia Economics and Finance 14, 23-29 (2014) 